\title{
Dry and rainy season estimations of giant otter, Pteronura brasiliensis, home range in the Yasuní National Park, Ecuador
}

\author{
Victor Utreras B. ${ }^{1,}$, Esteban Suárez R. ${ }^{2}$, Galo Zapata-Ríos ${ }^{3}$, Geovanna Lasso ${ }^{4}$ and Luis Pinos ${ }^{5}$
}

\begin{abstract}
The giant otter, Pteronura brasiliensis, is an endemic species of the main South American watersheds (Carter and Rosas, 1997; Groenendijk, 1998), and one of the largest predators of the rain forests and lowland wetlands of tropical South America (Mason and Macdonald, 1986). In past decades (1940-1960), commercial hunting fueled by the pelt industry decimated giant otter populations throughout its range and, although commercial hunting is no longer a major threat for this species, its survival is still threatened by widespread habitat destruction, resulting from increases in urban development, exploitation of timber, mining, environmental pollution, and hydroelectric power generation (Carter and Rosas, 1997). As a consequence, the giant otter is considered an endangered species throughout its geographical distribution (IUCN, 2000) and as a critically endangered species in Ecuador (Utreras and Tirira, 2001).
\end{abstract}

Although the last decade has witnessed interesting developments in our knowledge about distribution, population sizes, and behavior of the giant otter (Groenendijk, 1998; Scheck, 1999; Staib, 2005), there is still limited understanding about its ecological requirements and movement patterns. Among the information lacking about giant otters is their home range, defined as the surface area regularly used by and individual or a social group for feeding, reproduction and parenting (Burt, 1943; Ojasti, 2000), which is a critical variable that needs to be assessed in a variety of habitats. Home range size determines the amount of space required by an animal to meet its ecological needs under the influence of a given set of environmental constraints, including resource availability, and habitat quality (Flores and Bazzalo, 2004).

In the case of the giant otter, home-range analysis is complicated by the fact that, being an amphibious species, these animals use not only the water bodies where they hunt and move, but also a variable amount of riverine habitat where they construct dens, campsites, and latrines. In flooded forests like those frequently found in the Ecuadorian Amazon, estimation of giant otter home range is further complicated by the large seasonal variation in water level which dramatically changes the structure of the landscape. More specifically, discharge changes in the rivers may affect seasonal home range sizes of giant otters by 1) changing the extent of available riverine habitat, and 2) affecting prey availability (i.e. prey fish may disperse in the forest as they flood during the rainy season). Despite the potential importance of these factors, little is known about the use of space by giant otters and how it changes in response to seasonal variations in river water levels and the extent of riverine habitat. In this paper we present dry and rainy season estimations of the home range of three giant otter groups found in the flooded forests of the northeastern end of the Yasuní National Park (YNP), in the Ecuadorian Amazon.

This study was carried out during the dry seasons (August through March) of 2001, 2002 and 2003, in three river-lagoon systems: Añangu, Tambococha and Jatuncocha (Figure 1). Each of these systems consisted of a medium sized black-water river fed by small streams and ravines which together formed a lagoon of geological origin. In all the cases, the vegetation was characterized by a flooded forest (igapó) dominated by Coussapoa trinervia, Bactris riparia, and Montrichardia linifera (Sierra, 1999; Sánchez et al., 2002).

Large sections of each river where giant otter groups had been located (one group in each river) were traveled using a paddle-propelled canoe. Each river system section was traveled at least 50 times during the study period, in order to record the geographical location (GPS Garmin $12 \mathrm{XL}$ ) of every sign (i.e. latrines, campsites, dens, tracks) or direct observations of giant otter recorded during the survey. During previous surveys in these systems, we developed a photographic catalogue of the throat patterns of the individual otters in each group, which allowed us to confirm that there was only one giant otter group in each river, at least in the area covered by our sampling effort.

Based on the location of the records along the river and lagoon of each system, we estimated the dry season home range of each giant otter group by considering not only the effective surface of the river or lagoon where the animals were recorded, but also the area of riverine habitat used by the giant otters during the dry season. Thus, home range for each giant otter group was estimated as:

DSHR $=(($ DAR $\times$ MRW $)+(2 \times($ PDS*DAR $))+($ TPL $\times$ PDS $)$ + LSA, where DSHR is the estimated dry season home range; DAR is the distance along the channel of the river between the two most extreme signs or direct observations of each giant otter group; MRW is the mean river width (calculated from 35, 38 and 16 measurements taken every $500 \mathrm{~m}$ along Tambococha, Jatuncocha and Añangu,

\footnotetext{
${ }^{1}$ Wildlife Conservation Society. San Franciso 441 and Mariano Echeverría. P.O. Box 17-21-168. Quito, Ecuador. E-mail: vutreras@wcs.org. * Author for correspondence.

${ }^{2}$ Wildlife Conservation Society. San Franciso 441 and Mariano Echeverría. P.O. Box 17-21-168. Quito, Ecuador. E-mail: esuarez@wcs.org. ${ }^{3}$ Wildlife Conservation Society. San Franciso 441 and Mariano Echeverría. P.O. Box 17-21-168. Quito, Ecuador. E-mail: gzapata@wcs.org. ${ }^{4}$ Pontificia Universidad Católica del Ecuador. Escuela de Ciencias Biológicas. Quito, Ecuador. E-mail: geovalassso@yahoo.com.

${ }^{5}$ Universidad Central del Ecuador. Escuela de Biología y Química.Quito, Ecuador. E-mail: luispinos_ec@yahoo.com.
} 
respectively); PDS is the mean of the perpendicular distances between the river shore and each giant otter sign found in the forest; TPL is the total perimeter of the lagoon; and LSA is the surface area of the lagoons where giant otter signs or direct observations were recorded. Although this method does not provide information on the intensity of habitat use within the calculated home range or about its real shape, we think that it offers a valid alternative to estimate the minimum space requirements of the giant otters, considering their use of the riverine habitats.

In order to estimate potential size of giant otter home ranges during the rainy season, for each river-lagoon system we calculated the area of flooded forest immediately adjacent to the stretch of the river channel that was identified as home range during the dry season. The area of flooded forest was derived from a 1: 50,000 vegetation map generated from satellite information from the year 2000 .

During the dry season, the Jatuncocha giant otter group had the largest home range $\left(2.75 \mathrm{~km}^{2}\right.$, Table 1$)$ which was 4.6 and 6 times greater than the home ranges of the giant otter groups at Tambococha $\left(0.59 \mathrm{~km}^{2}\right)$ and Añangu $\left(0.45 \mathrm{~km}^{2}\right)$, respectively (Table 1 , Figure 1$)$. This large difference in home range sizes was primarily due to the $2.2 \mathrm{~km}^{2}$ lagoon that the Jatuncocha River forms in this area. It is important to note that the giant otter group at Jatuncocha has been frequently observed hunting in the middle section of this water body, suggesting that our inclusion of the surface area of the lagoon in the home range calculation is not an overestimation. This conclusion is supported by Staib (2005) who reported giant otter groups commonly using extensive areas of lagoons and not only their shores. The smaller home range of the giant otter group at Añangu derives both from the shorter stretch of river used by the otters, and the narrower channel of the Añangu River. These large differences in home range, however, did not seem to relate to the sizes of the giant otter groups which had five individuals at Tambococha, and six individuals at both Jatuncocha and Añangu.
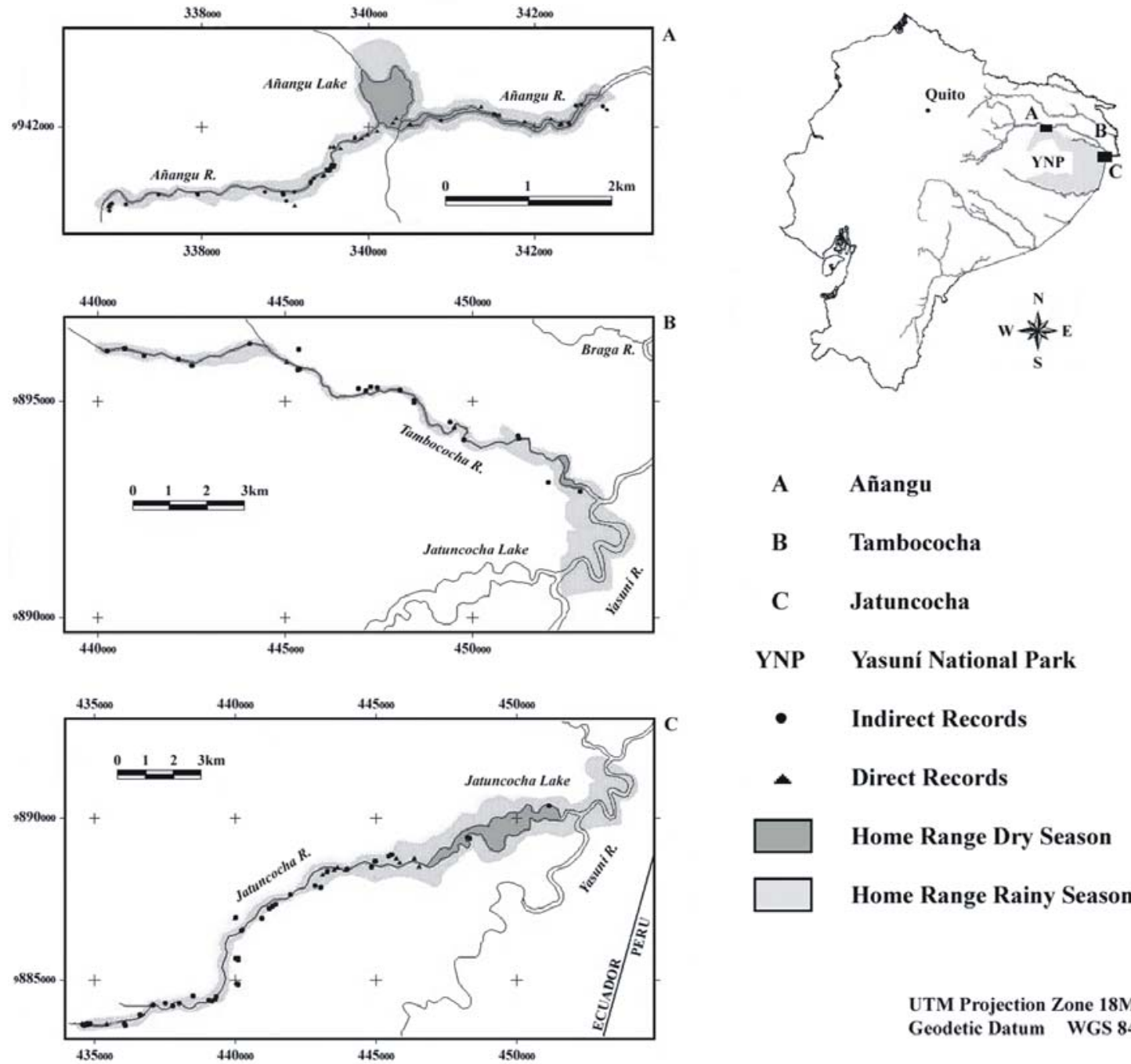

Home Range Dry Season

Home Range Rainy Season

UTM Projection Zone 18M Geodetic Datum WGS 84

Figure 1. Dry and rainy season estimations of giant otter home range in three river/lagoon systems in the Yasuní National Park, Ecuadorian Amazon. 
Table 1. Habitat characteristics and home range estimates for giant otter groups in three river-lagoon systems in the Yasuní National Park (Eastern Ecuador).

\begin{tabular}{lccccccc}
\hline & DAR $(\mathrm{km})$ & MRW $(\mathrm{m})$ & PDS $(\mathrm{m})$ & TPL $(\mathrm{km})$ & LSA $\left(\mathrm{km}^{2}\right)$ & DSHR $\left(\mathrm{km}^{2}\right)$ & RSHR $\left(\mathrm{km}^{2}\right)$ \\
\hline \hline Tambococha & 17.7 & 24.0 & 4.68 & 0.0 & 0.00 & 0.59 & 7.74 \\
Jatuncocha & 19.0 & 19.0 & 4.09 & 18.0 & 2.20 & 2.79 & 19.55 \\
Añangu & 8.18 & 13.2 & 3.65 & 2.1 & 0.28 & 0.45 & 1.98 \\
\hline \hline
\end{tabular}

Dry season home ranges were estimated from field observations, while rainy season estimates were calculated by adding the area of flooded forest adjacent to the stretch of river channel identified as dry season home range for each giant otter group. DAR: distance along the channel of the river between the two most extreme signs or direct observations of each giant otter group; MRW: mean river width; PDS: average of the perpendicular distances between the river shore and each giant otter sign found in the forest; TPL: total perimeter of the lagoon; LSA: surface area of the lagoons where giant otter signs or direct observations were recorded; DSHR: estimated dry season home range; RSHR: estimated rainy season home range

Across rivers, our estimates of the potential home range size of the giant otter groups during the rainy season ranged between 1.98 and $19.55 \mathrm{~km}^{2}$; these estimates were between 4 and 13 times greater than corresponding estimates of the home ranges during the dry season (Table 1). The largest difference between these estimates was found at Tambococha which had the largest amount of flooded forest adjacent to the river channel. Although we emphasize the fact that our rainy season home range sizes are estimates based on a detailed vegetation map of our three study sites, it is important to note that the giant otter groups at Jatuncocha and Tambococha have been effectively observed using areas of flooded forest that lie within the estimated rainy season home ranges that we present here. Similarly, Duplaix (1980) reported that she could not observe giant otter groups during the rainy season, as they migrated into flooded forest areas. In this sense, our results disagree with those presented by Laidler (1984), Shenk (1999) and Staib (2005), who did not found differences between wet and dry season home ranges of giant otter in southeastern Peru.

Our estimates of dry season home range size vary widely between sites, but are well within the range of values reported by other authors. For example, Schenk (1999) and Staib (2005) estimated home range sizes between 0.55 and $1.08 \mathrm{~km}^{2}$ for several giant otter groups in eastern Peru. In contrast, our estimates of rainy season home range sizes are consistently higher, reflecting the potential importance of taking into account the amount of flooded habitat potentially used by giant otter groups during the rainy season (Figure 1). Home range estimates as large as those calculated in our study have been previously reported in Suriname $\left(20 \mathrm{~km}^{2}\right.$; Laidler, 1984); in that case, however, the considerable size of the home range was due to the use of a large lagoon by the otter group, and not to the inclusion of the area of floodable habitat in the estimation.

Although our results do not shed light on the factors that determine the effective size of the home range of giant otter groups, our estimates of the potential area used by these animals during the rainy season offer a different perspective on the habitat needs of the species. While most home range estimates for giant otter are generated with data from the dry season, when otters concentrate in areas immediately adjacent to the river channels, we suggest that habitat requirements and availability of giant otter may be dramatically different during the rainy season; this may be especially important in regions where topography and predominant climatic patterns determine the development of large expanses of flooded forests with direct communications with the river channels used by giant otter groups. In such areas, park managers and conservationists need to pay attention not only to the rivers or lakes and their shores, but also to the amount of adjacent habitat that will be potentially flooded during regular rainy seasons; this additional habitat may be essential as hunting grounds or dispersal paths for otters during the rainy seasons, when environmental and biotic conditions in the rivers are dramatically different.

The partial overlapping of home ranges is a phenomenon that frequently occurs among many mammal species (e.g. Fornasari et al., 1994; Ferreras et al., 1997; Núñez et al., 2002), specially considering that home ranges are areas that are not actively defended by the individuals or groups. Our results suggest the potential of a partial home range overlap during the rainy season, when the home range sizes expand (Figure 1). This possibility, supported by observations made in the field, points out to an interesting avenue for new research regarding the behavioral interactions that could arise when different otter groups contact each other as they patrol or use their expanded rainy season home ranges.

Although we know very little about the real intensity and extent to which flooded forests areas are used by giant otter groups during the rainy season, this must depend on a complex interactions between climatic and hydrologic patterns, flooding levels, and the extent of flooded forest use by prey fish. Although this possibility was already suggested by Duplaix (1980), to our knowledge, these interactions remain largely unexplored and may be critical in order to understand 
the spatial and temporal dynamics of habitat use by giant otter groups.

We suggest that future research should focus on understanding how giant otter and their prey use their habitat during rainy season, in different settings with varying levels of flooding. In this sense, there is an urgent need to explore the use and development of alternative tools to elucidate the actual patterns of habitat use by the otters, including aspects related to habitat preference within their home ranges. Among these alternatives, the use of satellite or radiotransmitters appears as a logical possibility that should be considered in the near future. Another avenue for future research should consider the use of alternative methods for home range estimation, including those discussed by Anderson (1982) and Aymoré and Rudran (2004). Beyond estimating the home range of a species, these methods offer other parameters of biological importance that should be considered, such as the frequency and intensity of use of different areas within the home range.

\section{Acknowledgments}

This study was funded by Wildlife Conservation Society and USAID (Grant \# LAG-A-00-99-00047-00). The authors wish to thank Alonso Jaramillo (Ministry of the Environment), the staff of the Yasuní National Park and Norby López (EcoEcuador) for their collaboration and logistical support during this study. Special thanks to Nélio Barros, Mauricio Castillo, Friedman Koester, Nelsón Gallo, and two anonymous reviewers who provided valuable comments, and improved previous versions of this paper. Finally, many thanks to Paola Carrera, David Grefa, and to the members of the community of Añangu for their collaboration during the field phase of this study.

\section{References}

AnDERSON, D.J. (1982) The home range: a new nonparametric estimation technique. Ecology 63(1): 103-112.

Aymoré, A. AND RudRAn, R. (2004) Radiotelemetría em estudos populacionais. Pages 285-342 in CULLEN JR., L., RUDRAN, R. AND Valladares-Padua, C. (Ed) Métodos de Estudos em Biología da Conservacao \& Manejo da Vida Silvestre. Editora da Universidade Federal do Paraná/Fundação O Boticário de Proteção à Natureza, Curitiba, Paraná, Brazil.

BuRT, W.H. (1943) Territoriality and home-range concepts applied to small mammals. Journal of Mammalogy 24: 346-352.

Carter, S.K. And Rosas, F.C.W. (1997) Biology and conservation of the giant otter (Pteronura brasiliensis). Mammal Review 27(1): 1-26.
Duplaix, N. (1980) Observations on the ecology and behavior of the giant river otter (Pteronura brasiliensis) in Suriname. Revue D’Ecologie (Terre Vie) 34: 496-620.

Ferreras, R., Beltrán, J.F., Aldama, J.J. And Delibes, M. (1997) Spatial organization and land tenure system of the endangered Iberian Lynx (Lynx pardinus). Journal of Zoology 243: 163-189.

Flores, P.A.C. AND BAzZalo, M. (2004) Home ranges and movement patterns of the marine tucuxi dolphin (Sotalia fluviatilis), in Baía Norte, southern Brazil. The Latin American Journal of Aquatic Mammals 3(1): 37-52.

Fornasari, L., BotToni, L., SACCHI, N. AND MASSA, R. (1994) Home-range overlapping and sociosexual ralationships in the red-backed shrike (Lanius collurio). Ethology, Ecology and Evolution 6(2): 169-177.

GroenendijK, J. (1998) A review of the distribution and conservation status of the giant otter (Pteronura brasiliensis), with special emphasis on the Guayana shield region. Netherlands Commite for IUCN, Amsterdam.

IUCN (2000) IUCN Red List Categories. IUCN Species Survival Commission. $51^{\text {th }}$ Meeting of the IUCN Council, Gland, Switzerland.

LAIDLER, P.E. (1984) The behavioural ecology of the giant otter in Guyana. PhD thesis, University of Cambridge, England. 296 pp.

Mason, C.F. AND MacdonAld, S.M. (1986) Otters: Ecology and Conservation. Cambridge University Press, Cambridge, England.

NúÑEZ, R., Miller, B. AND LindzeY, F. (2002) Ecología del jaguar en la reserva de biosfera Chamela-Cuixmala, Jalisco, México. Pages 107-126 in Medellín, R.A., Equihua, C., ChetKiewicz, C.L.B., Crawshaw, P.G., Rabinowits, A., Redford, K.H., Robinson, J.G., SANDERSON, E.W. AND TABER, A.B. (Eds) El Jaguar en el Nuevo Mileño. Fondo de Cultura Económica, Universidad Nacional Autónoma de México y Wildlife Conservation Society. México, D.F.

OJASTI, J. (2000) Manejo de fauna silvestre neotropical. F. Dallmeier (ed.). SIMAB Series No. 5 Smithsonian Institution/ MAB Program, Washington, D.C. 290 pp.

SÁnchez, G., NeILl, D. AND RodríGueZ, F. (2002) Clasificación de cobertura vegetal del Parque Nacional Yasuní y el Territorio Huaorani. EcoCiencia-WCS-Herbario Nacional del Ecuador. Quito, Ecuador.

SIERRA, R. (Ed) (1999) Propuesta preliminar de un sistema de clasificación de vegetación para el Ecuador continental. EcoCiencia. Quito, Ecuador.

SCHENCK, C. (1999) Lobo de río Pteronura brasiliensis. Presencia, uso de hábitat y protección en el Perú. GTZ-INRENA, Lima, Peru.

Staib, E. (2005) Eco-Etología del lobo de Río (Pteronura brasiliensis) en el sureste del Perú. INAENA - Sociedad Zoológica de Francfort Perú, Lima, Peru.

Utreras, V. AND Tirira, D. (2001) Nutria gigante (Pteronura brasiliensis). Pages 61-63 in TIRIRA, D. (Ed), Libro rojo de los mamíferos del Ecuador. Quito, Ecuador. 